$\underline{\text { Article }}$

\title{
Between Growth and National Security in Host Countries: FDI Regulation and Chinese Outward Investments in Australia's Critical Infrastructure
}

\author{
Irina Heim ${ }^{1}$ (1) ${ }^{\text {, }}$, Natalia Ribberink ${ }^{2}$ (1) \\ 1 University of Reading, UK, ${ }^{2}$ Hamburg University of Applied Sciences, Germany \\ Keywords: economic development, national security, foreign direct investments, emerging countries, extractive industry, critical infrastructure, \\ investment policy, australia, china
}

https://doi.org/10.46697/001c.19506

\section{AIB Insights}

Vol. 21, Issue 1, 2021

\begin{abstract}
To achieve sustainable growth, China facilitates outward foreign direct investments (FDI) in natural resources and technology through large supportive policies and massive financing, particularly through the expansion of its state-owned companies into foreign markets. This trend has accelerated economic growth in Australia but has also raised national security concerns regarding foreign investments. This paper discusses the problem of balancing foreign investment and national security and aims to stimulate discussion on the extent of regulations necessary for FDI in critical infrastructure. This paper will be interesting for host-country policymakers balancing inward FDI and national security concerns through appropriate screening mechanisms.
\end{abstract}

\section{INTRODUCTION}

There are growing concerns related to geopolitical interests behind Chinese FDI $^{1}$ in Australia and other countries, although Chinese FDI flows into Australia have been falling precipitously from their peak in 2015-2016. This decline can be attributed to some regulatory/legislative measures discussed in this paper, changes in China's internal domestic investment policy including scrutiny of outbound investment and stricter capital controls, but also more generally, to the deterioration of the economic relationship between two countries.

State ownership, especially in strategically important industries, reflects a high level of governmental influence behind some investments. Beyond the ownership structure, governmental involvement is clearly identified through financial resources provided by banks with government participation, state-owned enterprises (SOEs), and institutions often having better access to finance. Thus, the primary focus of Chinese governmental support programs like the Chinese "Go out" policy and the "Belt and Road Initiative" is on encouraging SOEs ownership of strategic assets raised concerns regarding their role (Ufimtseva, 2020). The trend of Chinese investment in sensitive industries ${ }^{3}$ has raised concerns in host countries regarding the sovereignty of these industries, which are critical to host countries' survival, i.e., national interests or national security (Lai, 2021). Yet it is unclear how to find the right balance between security and growth resulting from foreign investments especially in the context of additional vulnerability in times of COVID-19 crisis and related adversity. The pandemic transformed international business, global value chains, the role of governments in regulating foreign direct investment (FDI), the response of policymakers to the challenges such as missing national production facilities for critically important goods and services (medical ventilators, face masks, vaccines, medical, and technological capacities).

The purpose of this paper is to review Australian regulations aimed at monitoring and controlling FDI activity in Australia's critical infrastructure. It identifies implications for policymakers in countries considering the introduction of regulations for FDI (e.g., major recipient countries for Chinese FDI in Africa) or countries currently implementing such policies (e.g., European Union countries, for example, the EU where the FDI screening regulation became fully operational in October 2020). The other countries that recognise and respond to national security interests by in-

\footnotetext{
a Corresponding author; irina.heim@henley.ac.uk

1 For the purpose of this paper, FDI exclusively refers to Chinese outward FDI in host countries.

2 The "Go out" policy is a strategy to encourage Chine enterprises to invest overseas; the Belt and Road policy is a global infrastructure development strategy focused on investments in relevant industries.

3 Sensitive businesses include media, telecommunications, transport, defense, military-related industries and activities, encryption and securities technologies, communications systems, extraction of uranium or plutonium, and the operation of nuclear facilities.
} 
Table 1. Top foreign investors in Australia, AUD \$ billion.

\begin{tabular}{|c|c|c|c|c|c|c|c|}
\hline $\begin{array}{c}\text { Rank in } \\
2019\end{array}$ & Economy & 2017 & 2018 & 2019 & $\begin{array}{l}\% \text { of } \\
\text { total }\end{array}$ & $\begin{array}{l}\% \text { change } 2018 \\
\text { to } 2019\end{array}$ & $\begin{array}{l}5 \text {-year trend \% } \\
\text { growth }\end{array}$ \\
\hline 1 & United States & 912.9 & 949.2 & 983.7 & 25.6 & 3.6 & 4.1 \\
\hline 2 & United Kingdom & 498.4 & 584 & 686.1 & 17.8 & 17.5 & 6.8 \\
\hline 3 & Belgium & 305.1 & 315.5 & 348.1 & 9.1 & 10.4 & 9.1 \\
\hline 4 & Japan & 226.5 & 233.9 & 241.1 & 6.3 & 3.1 & 4.8 \\
\hline 5 & $\begin{array}{l}\text { Hong Kong (SAR of } \\
\text { China) }\end{array}$ & 108.7 & 122.9 & 140.7 & 3.7 & 14.5 & 13.1 \\
\hline
\end{tabular}

Source: authors based on Australian Government, https://www.dfat.gov.au/ (SAR stands for the special administrative region of China).

troducing FDI policies include the UK (with the National Security and Investment Bill being announced in December 2019), the US (notification of foreign involvement in critical technologies, infrastructure, and data), Japan (extended the scope of sensitive sectors), and China itself (unified investment screening regime).

This paper is based on a review of academic and business literature, reports, and policy papers analysing FDI regulations in Australia's critical infrastructure. It touches upon the concept of national security and evaluates policymaking implications for international business in Australia suggesting an FDI screening framework.

\section{THE NEED FOR FDI REGULATION: THE AUSTRALIAN EXPERIENCE}

Although Australia has relaxed FDI regulation after the financial crisis in 2008, recently, in the current Australia-China climate, FDI regulation has been again strengthened. Within Australia, some industries are more restricted than other industries compared with the OECD industry average. In Australia, FDI in critical infrastructure is regulated because it is believed that foreign investments can interfere with national interests and security. Critical infrastructure is defined as infrastructure that is crucial to a country's national and economic security, public health, safety, or any combination of these (Moteff, 2010).

Concerns regarding the security of critical infrastructure expressed by public opinion are essential and taken seriously in Australia. However, these concerns date back to the 1950s, and Australians have been conservative toward the inflow of foreign capital since the US and Japan started to invest long before China; the US and Japan are currently top foreign investors in the Australian economy (Table 1). These concerns, however, have decreased over time, because American and Japanese investment engagement in Australia was less influenced by their home governments than Chinese investments. Recent research by Laurenceson, Bretherton, Burke, \& Wei (2019) found that the Australian public is concerned by the overall government-supported share of foreign ownership in investments, rather than specific anxiety towards Chinese investments.

The Chinese governmental influence is foremost evident in the resource sector, which plays a significant role in Aus-

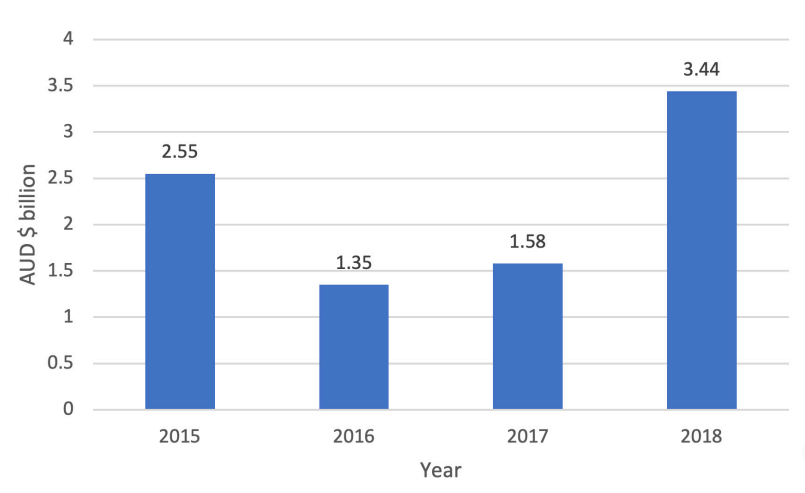

Figure 1. Chinese Investment in the Australian healthcare sector (AUD \$ billion).

Source: authors' own depiction based on MistryFallahi, https://www.mistryfallahi.com.au/.

tralia's economy. The state plays an important role in the Chinese economy, and a big share of their outward FDI in the Australian resource sector is invested through SOEs. Although the resource sector is not directly considered a critical industry, resources are indirectly critical because they are an important driver of the economy and employment and provide energy for Australia's infrastructure, power grids, and military sector. The concerns of the Australian Government and politicians are that foreign SOEs not only pursue commercial interests but also jeopardise national interests and exercise control over resources in Australia and, therefore, SOEs are viewed with suspicion (CuervoCazurra, 2018).

The healthcare sector is also regarded as a critical sector in Australia. In recent years, Chinese FDI in healthcare has soared, partly due to "Healthy China 2030", a long-term structural reform to address rising healthcare challenges (Figure 1). Chinese hospitals and healthcare service providers have targeted Australian healthcare supplement producers, service companies, pharmaceutical companies, and construction companies. Chinese investors' interest in Australian companies that can export their products to China is reflected in the export statistics of pharmaceutical products (Figure 2).

Australian transport infrastructure, especially maritime infrastructure, has also gained importance for Chinese in- 
vestors. Between 2013 and 2017, Melbourne, Newcastle, and Darwin ports have been acquired by Chinese state-owned consortiums. These investments are important strategic assets for the BRI project. Furthermore, because of growing housing demand which remains high from population growth, Australia is seen by Chinese investors as a future growth market and a hedging instrument against a downturn in their home country construction sector (Sacilotto \& Loosemore, 2018). Specific and proven risks associated with Chinese investments in the Australian construction industry include low wages and various compliance issues (i.e., poor safety standards, use of asbestos in materials, and overall low quality of work).

Besides, China invests in research and development resources comparable to those in the European Union while relevant expenditures are declining in Australia. Taking into consideration the financial resources available, China can easily accelerate the research and development and leave many countries, including Australia far behind. This creates demand for technologies that are missing and that can be filled in by Chinese companies.

The major instrument of Australia's FDI regulatory framework is the 1975 Foreign Acquisitions and Takeovers Act (FATA). FATA relates to the foreign acquisition or foreign control of land, business enterprises, and mineral rights and rests on a case-by-case review basis. The Foreign Investment Review Board (FIBR) provides early and comprehensive advice on national security concerns. The FIRB reviews FDI activity above certain thresholds (acquisitions of $20 \%$ or more in Australian entities valued at more than AUD \$266 million), before consulting the Treasurer who approves or rejects proposals.

Despite a functional FDI review process, there has been a high FDI approval rate in Australia over the last decade. For example, according to the FIBR Annual Report, in 2018-2019, 48\% of all FDI applications were approved without conditions, $44 \%$ were approved with conditions, $7 \%$ were withdrawn prior to a decision (with around $85 \%$ of these related to residential real estate), $1 \%$ were exempt, and only one application was rejected. There has been only a handful of investment proposal rejections in the past decade, including rejection of investment proposals from the UK, the US, Japan, and China. However, the official rejection rates may not encompass informal rejections where Australian companies are simply told not to go ahead (Kehoe, Bleby, Wootton, Lenaghan, \& Tillett, 2021).

Finding the balance between the FDI attraction, regional economic integration commitment, and national security will be a significant challenge for FDI recipient countries in the aftermath of COVID-19. In Australia, changes to the FDI review process started on 29 March 2020: the government announced that the monetary review thresholds for all foreign investment subject to the FATA were temporarily removed to safeguard national interest. On 5 June 2020, the government announced another major change to Australia's FDI framework, representing the most comprehensive reform of the FATA, and on 9 December 2020, this reform was ratified by Parliament. It requires foreign investors to seek approval for all investments in sensitive national security land or businesses (including starting such a business), regardless of value.

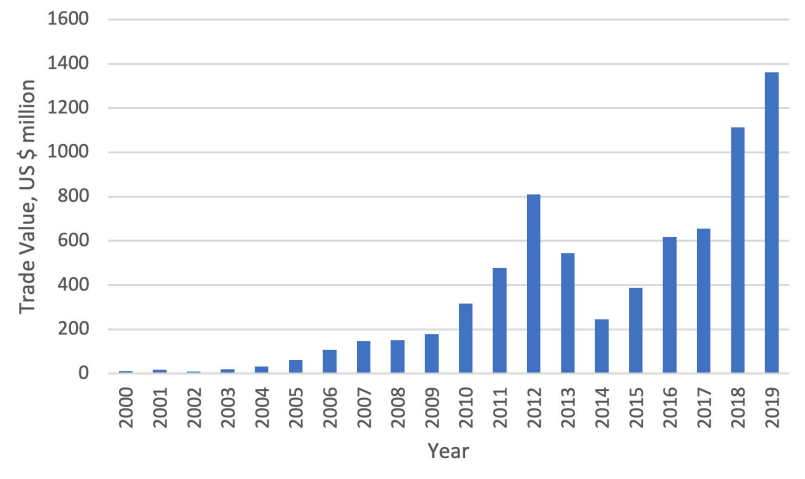

\section{Figure 2. Australian exports of pharmaceutical products (SITC code 54) to China 2000-2019, trade value, USD \$ million.}

Source: authors' own depiction based on United Nations COMTRADE database, https://comtrade.un.org/data/.

Unfortunately, there is a shortage of research towards the question of how to find the balance between the sceptical public attitudes and positive FDI effects on economic growth in host countries. When some advocate for clearly defined FDI policy (Cuervo-Cazurra, 2018), others observe the prevailing trend of ambiguity in relation to inward FDI policy (Lai, 2021). Future research should examine the factors driving opposition to FDI in this balancing act (Tingley, $\mathrm{Xu}$, Chilton, \& Milner, 2015). We suggest that the bilateral investment will be successful if its results are perceived positively externally and internally (in the first instance by both countries), and therefore will find policy support. The decision-makers should take into account industry sensitivity characteristics, investors characteristics (e.g., degree of state participation), and current economic needs such as the need for job creation, availability of technology, housing demand, or the availability of financial resources (see Figure 3). The assistance of the host country with the development of technology can be an increasingly important factor. Recent research shows examples of such cooperation whereby Chinese companies have transferred domestic practices to the Australian market, raising their competitive advantage in their original investment industry, as well as in the new industries (Li \& Hendrischke, 2020). As we can also observe during the COVID-19 pandemic, in advanced economies, the public perceptions and attitudes will definitely have an influence on policymakers' responses toward one or another exogenous shock, epidemiological, economic, or the combination of both. Therefore, the policy should mitigate the effect of negative public perception.

\section{POLICY RECOMMENDATIONS}

We offer some recommendations to policymakers responsible for balancing inward FDI and national security concerns through appropriate screening mechanisms:

- Policymakers in countries introducing FDI screening regimes should carefully evaluate all details of FDI review mechanisms and related regulations before implementing policies. They should evaluate not only 
potential economic factors such as potential FDI spillovers, type of investors and possible state ownership, industry characteristics, but also non-economic factors such as internal and external stakeholders' support and particular adversity situations related to national security concerns. Practically, policymakers should develop a list of assessment criteria that need to be considered when evaluating each section in the suggested FDI screening framework. Policymakers should aim at developing requirements that provide clarity of review mechanisms, but also address security concerns. Foreign investors definitely expect more clear and simple guidance on screening requirements.

- We propose a multi-pronged screening approach, where some industries (i.e., technologies with dualuse - nuclear, artificial intelligence, big data, chemical, biological, thermal imaging; some healthcare such as virology and epidemiology, imaging systems, etc.) would get more attention.

- The first possible approach is the "horizontal" one (i.e., to define the list of sensitive industries). Governments should not support attempts to expand the list of protected industries hindering competition and collaboration. However, the list of such industries could be expanded based on the recent experience of countries with shortfalls of critical healthcare goods such as face masks, medical ventilators, and vaccines.

- Another possible approach is the "vertical" one. This implies that instead of earmarking certain industries, the sensitivity of the particular FDI case should be evaluated within a given industry. Policymakers can combine two approaches to reduce the evaluation workload. They should also consider collaboration with research and industry organisations on an assessment of FDI cases.

- Governments should support the development of sensitive technologies through the establishment of industry growth centres by providing incentives that facilitate collaboration between industry, research, and universities, allowing access to global value chains. This can also include collaboration with foreign partners built on mutual trust. Concerns regarding the use of technologies for non-commercial purposes can be mitigated by inspecting the technologies and technological goods in such centres.

- Finally, the screening procedures should establish a unified approach to all countries (not only China) and should treat investors fairly taking into consideration the type of investor, industry, and interests and perception of society in host countries.

\section{CONCLUSION}

Outward FDI is an important driver of globalisation and strategic interests for countries such as China. From this perspective, Australia is an attractive host country for Chinese investments because it is a developed country with an advanced market economy and abundant natural resources. Chinese investment projects encompass investments in critical infrastructure, which have often been a subject of concern in Australia and many other countries. For exam-

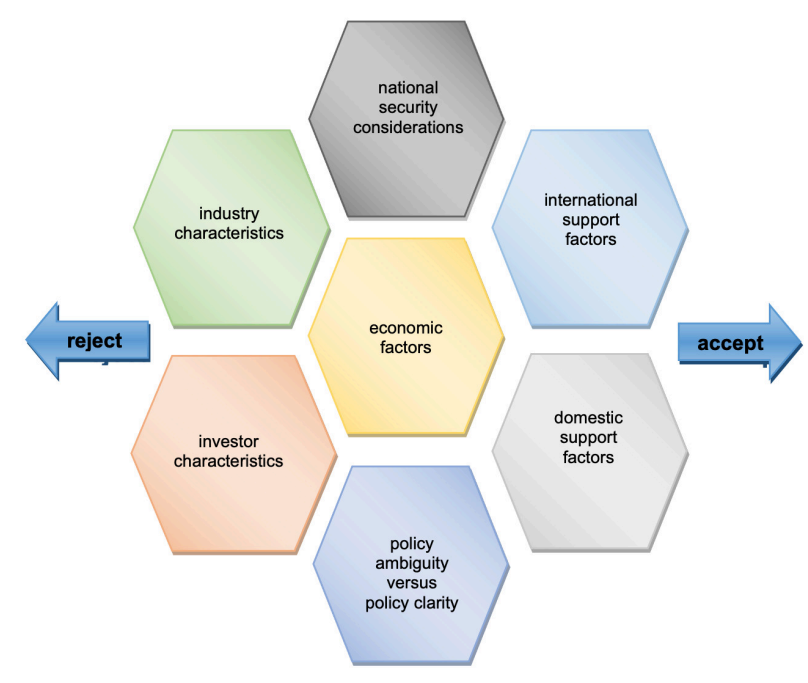

Figure 3. FDI screening framework.

Source: authors' own depiction based on examined literature.

ple, policymakers in several countries are considering introducing or are already implementing similar FDI review mechanisms. The term "national interest" is specifically used by the Australian Government to describe the community's concerns about economic, social, and political matters regarding Chinese investments and investments from other countries. Recent initiatives launched by China such as the BRI, multilateral commitments, and external shocks like the COVID-19 pandemic may cause a major revision of the "national security" concept in various countries and lead to the need for re-design and modification of relevant legal frameworks. Overall, we suggest that in a post-pandemic world, governments should carefully re-evaluate all details of FDI review mechanisms and related regulations and apply it only in industries directly concerned with national interests.

\section{ACKNOWLEDGEMENTS}

We are grateful for extremely helpful comments from guest editors and three anonymous reviewers.

\section{ABOUT THE AUTHORS}

Irina Heim is a post-doctoral researcher at Henley Business School, University of Reading (UK). Irina also holds academic posts at the University College London. She gained extensive industry experience in the field of international business when working with a global ICT organization. In her recent book Kazakhstan's diversification from the natural resource sector: strategic and economic opportunities (Palgrave Macmillan) she discusses the economic diversification opportunities for resource-rich countries arising from foreign investments. 
Natalia Ribberink in addition to her professorship at the Hamburg University of Applied Sciences Natalia Ribberink holds visiting professor positions at the University of Rhode Island (USA), California State University Long Beach (USA), and has a position of the external faculty member at the Utrecht University of Applied Sciences (The Netherlands). Before being appointed as a professor, Natalia spent five years in the German aviation industry within a large airline alliance.

Submitted: September 21, 2020 EST, Accepted: February 09, 2021 EST 


\section{REFERENCES}

Cuervo-Cazurra, A. 2018. Thanks but no thank: Stateowned multinationals from emerging markets and host-country policies. Journal of International Business Policy, 1: 128-156.

Kehoe, J., Bleby, M., Wootton, H., Lenaghan, N., \& Tillett, A. 2021, January 12. Treasurer blacklist China investments. Financial Review. https://www.afr.com/ politics/federal/treasurer-imposes-informal-ban-on-c hina-investments-20210112-p56thm.

Lai, K. 2021. National security and FDI policy ambiguity: A commentary. Journal of International Business Policy. https://doi.org/10.1057/ s42214-020-00087-1.

Laurenceson, J., Bretherton, H., Burke, P. F., \& Wei, E. 2019. Chinese investment in Australian infrastructure assets: Accounting for local public preferences. China Economic Journal, 12(1): 77-92.
Li, W., \& Hendrischke, H. 2020. Local integration and co - evolution of internationalizing Chinese firms. Thunderbird International Business Review, 62(4): 425-439.

Moteff, J. 2010. Critical infrastructures: Background, policy, and implementation. Washington, DC: Congressional Research Service, Library of Congress.

Sacilotto, J., \& Loosemore, M. 2018. Chinese investment in the Australian construction industry: The social amplification of risk. Construction Management and Economics, 36(9): 507-520.

Tingley, D., Xu, C., Chilton, A., \& Milner, H. V. 2015. The political economy of inward FDI: Opposition to Chinese mergers and acquisitions. The Chinese Journal of International Politics, 8(1): 27-57.

Ufimtseva, A. 2020. The rise of foreign direct investment regulation in investment-recipient countries. Global Policy, 11(2): 222-232. 